\title{
Variations in food and drink advertising in UK monthly women's magazines according to season, magazine type and socio-economic profile of readers: a descriptive study of publications over 12 months
}

\author{
Jean Adams", Emma Simpson and Martin White
}

\begin{abstract}
Background: Overweight and obesity are recognised nationally and internationally as key public health challenges. Food and drink advertising is one of the array of factors that influence both diet and physical activity choices and, hence, body weight and obesity. Little previous work has focused on food and drink advertising in magazines. We studied food and drink advertising in a wide range of popular UK monthly women's magazines published over a full year. We explored differences in the prevalence of food and drink advertising and the type of food and drinks advertised according to season, magazine type and socio-economic profile of readers.
\end{abstract}

Methods: All advertisements in all issues of 18 popular UK monthly women's magazines published over 12 months were identified. For each food or drink advertisement, branded food and drinks were noted and categorised into one of seven food groups. All analyses were at the level of the individual advertisement.

Results: A total of 35053 advertisements were identified; 1380 (3.9\%) of these were for food or drink. The most common food group represented was 'food and drinks high in fat and/or sugar' (28.0\% of food advertisements), the least common group was 'fruits \& vegetables' (2.0\% of food advertisements). Advertisements for alcohol accounted for $10.1 \%$ of all food advertisements. Food and drink advertisements were most common in summer, general interest magazines, and those with the most affluent readerships. There were some differences in the type of food and drink advertised across season, magazine type and socio-economic profile of readers.

Conclusions: Food and drink advertisements represented only a small proportion of advertisements in UK women's monthly magazines. Food and drink advertisements in these magazines feature a high proportion of 'less healthy' foods. There were a number of differences across season, magazine type and according to the socioeconomic profile of readers in the prevalence of food and drink advertisements. Fewer differences were seen in the type of food and drinks advertised.

\section{Background}

Overweight and obesity are recognised nationally and internationally as key public health challenges [1,2]. Advertising is one of the array of environmental and social factors that influence both diet and physical activity choices and, hence, body weight and obesity [3]. The

\footnotetext{
* Correspondence: j.m.adams@ncl.ac.uk
Institute of Health \& Society, Newcastle University, Newcastle upon Tyne,

* Correspondence: j.m.adams@ncl.ac.uk NE2 4HH, UK
}

role of television food advertising in food choice and obesity, particularly amongst children, has received substantial research attention over recent years $[4,5]$, but a variety of other forms of food advertising exist. Magazines are a common source of diet-related information $[6,7]$ and advertising in print media can reinforce brand images and communicate more detailed information than television advertising [8]. In 2007 around $£ 92.4 \mathrm{~m}$ was spent on food advertising in print media in the UK 
- representing $19.1 \%$ of all food advertising spend in the UK [9].

Most published research on food advertising in magazines focuses on US publications [6,10-12]. This work suggests that food advertisements vary according to the population groups that different magazines are read by. For instance, US magazines aimed at white women contained more advertisements for fruit and vegetables, while those aimed at African American women contained more advertisements for alcohol [11]. These differences may contribute to the difference in body weight between these two groups, with white women tending to have a lower risk of obesity than African American women [13]. Differences in food advertising according to the socioeconomic profile of magazine readers were also seen in recent work from the UK [14]. Fruit and vegetables and alcoholic beverages were more commonly advertised in magazines with more affluent readerships, whilst convenience foods were more commonly advertised in magazines with less affluent readerships [14].

Previous work on magazine food advertising tends to be limited in terms of the number of publications or consecutive issues studied $[6,7,10-12,14,15]$. Thus, results may be unduly influenced by one particular publication, or the time of year studied. To overcome these shortcomings, we studied food advertising in a wide range of popular UK monthly women's magazines published over a full year. We explored differences in the prevalence of food and drink (collectively referred to as 'food' throughout) advertising and the type of foods advertised according to season, magazine type and socio-economic profile of readers.

\section{Methods}

\section{Publications of interest}

All UK monthly magazines listed in the National Readership Survey (NRS) [16] as a women's magazine with a mean readership of over 500,000/month during October 2006 - September 2007 were considered for inclusion. Six publications were excluded - four supermarket magazines not readily available outside the supermarkets they are published by (Asda Magazine, Sainsbury's Magazine, Somerfield Magazine and Waitrose Food Illustrated) and two magazines aimed at teenagers (Bliss and Sugar) that are covered by statutory and voluntary regulations on food advertising to children [17]. Annual subscriptions to the remaining 18 publications were purchased in spring 2008 (Table 1).

\section{Data abstraction}

All stand alone advertisements (excluding product placement in editorial content, money off coupons, advertorials, fliers and supplements) were identified and the product advertised and size of each advertisement (in printed pages) recorded. The term 'food advertisements' was used to describe all advertisements for branded food and drink products, but excluding dietary supplements and baby food. All branded products shown in food advertisements were recorded.

\section{Categorisation of food advertisements}

Food advertisements were categorised into one of seven food groups, based on the five groups in the Food Standards Agency's 'EatWell Plate' [18] plus alcohol, and other products not otherwise classifiable ('other foods'). When more than one branded product was shown in an advertisement, categorisation was based on the most prominently displayed product (i.e. the largest). Within each food group, foods were also categorised into subgroups to give an indication of the main types of food represented by each food group. These sub-groups were defined post-hoc (see Additional file 1, Table S1).

\section{Socio-economic profile of readers}

As previously [14], National Readership Survey data on the social class breakdown of adult readers was used to calculate a metric reflecting the socio-economic profile of readers of each magazine: the ratio of the mean percentage of individuals in social classes C2, D and E (manual, less affluent social classes) who read the magazine each month to the mean percentage of individuals in social classes A, B and C1 (non-manual, more affluent social classes) who read the magazine each month. A higher "C2DE: $\mathrm{ABC1}$ " ratio indicates that the magazine tends to be read more by individuals in less affluent social classes than those in more affluent social classes. Magazines were grouped into three affluence tertiles based on this ratio (Table 1).

\section{Season and magazine type}

Four seasons were assigned based on the cover month of publication: spring (March, April and May), summer (June, July and August), autumn (September, October and November), and winter (December, January and February). Three magazine types were assigned: lifestyle and beauty; food and homes; and general interest (Table 1).

\section{Analysis}

Differences in the distribution of food categories across seasons, magazine types and affluence tertiles were explored using chi-squared tests. All analyses was performed using SPSS 15.0 and, due to the large number of tests performed, a $\mathrm{p}$-value of $<0.01$ was taken to indicate statistical significance.

\section{Results}

The total sample included 18 publications, 213 issues, 49289 pages and 35053 advertisements. Of these, 1380 
Table 1 UK monthly women's magazines included in study

\begin{tabular}{|c|c|c|c|c|c|c|c|c|c|c|}
\hline \multirow[t]{2}{*}{ Publication } & \multirow[t]{2}{*}{$\begin{array}{l}\text { Cover price of } \\
\text { first issue }(£)\end{array}$} & \multirow[t]{2}{*}{$\begin{array}{l}\mathrm{N} \text { issues } \\
\text { per year }\end{array}$} & \multirow[t]{2}{*}{$\begin{array}{l}\text { First issue in } \\
\text { sample }\end{array}$} & \multirow[t]{2}{*}{$\begin{array}{l}\text { Magazine } \\
\text { type }\end{array}$} & \multirow[t]{2}{*}{$\begin{array}{l}\text { Monthly } \\
\text { readership } \\
(1000 \mathrm{~s})^{1}\end{array}$} & \multicolumn{3}{|c|}{$\begin{array}{l}\text { Percentage of } \\
\text { population who read } \\
\text { magazine } e^{1,2}\end{array}$} & \multirow[t]{2}{*}{$\begin{array}{l}\text { C2DE: } \\
\text { ABC1 } \\
\text { ratio }^{6}\end{array}$} & \multirow[t]{2}{*}{$\begin{array}{l}\text { Affluence } \\
\text { tertile }^{7}\end{array}$} \\
\hline & & & & & & Overall $^{3}$ & $\mathrm{ABC}^{4}{ }^{4}$ & $C 2 \mathrm{DE}^{5}$ & & \\
\hline $\begin{array}{l}\text { BBC Good } \\
\text { Food }\end{array}$ & 3.10 & 12 & April 2008 & $\begin{array}{l}\text { Food and } \\
\text { homes }\end{array}$ & 1149 & 2.4 & 3.2 & 1.3 & 0.41 & Most \\
\hline Company & 2.00 & 12 & May 2008 & $\begin{array}{l}\text { Lifestyle and } \\
\text { beauty }\end{array}$ & 647 & 1.3 & 1.6 & 1.0 & 0.63 & Least \\
\hline Cosmopolitan & 3.20 & 12 & April 2008 & $\begin{array}{l}\text { Lifestyle and } \\
\text { beauty }\end{array}$ & 1756 & 3.6 & 4.6 & 2.4 & 0.52 & Middle \\
\hline $\begin{array}{l}\text { Country } \\
\text { Living }\end{array}$ & 3.50 & 12 & April 2008 & $\begin{array}{l}\text { Food and } \\
\text { homes }\end{array}$ & 798 & 1.6 & 2.2 & 0.9 & 0.41 & Most \\
\hline Elle & 3.30 & 12 & May 2008 & $\begin{array}{l}\text { Lifestyle and } \\
\text { beauty }\end{array}$ & 854 & 1.8 & 2.2 & 1.2 & 0.55 & Middle \\
\hline Glamour & 2.00 & 12 & April 2008 & $\begin{array}{l}\text { Lifestyle and } \\
\text { beauty }\end{array}$ & 1236 & 2.6 & 3.3 & 1.7 & 0.52 & Middle \\
\hline $\begin{array}{l}\text { Good } \\
\text { Housekeeping }\end{array}$ & 3.30 & 12 & May 2008 & $\begin{array}{l}\text { General } \\
\text { interest }\end{array}$ & 1589 & 3.3 & 4.5 & 1.8 & 0.40 & Most \\
\hline Hair & 2.99 & 10 & June 2008 & $\begin{array}{l}\text { Lifestyle and } \\
\text { beauty }\end{array}$ & 677 & 1.4 & 1.5 & 1.3 & 0.87 & Least \\
\hline $\begin{array}{l}\text { Homes \& } \\
\text { Garden }\end{array}$ & 3.40 & 12 & May 2008 & $\begin{array}{l}\text { Food and } \\
\text { homes }\end{array}$ & 878 & 1.8 & 2.3 & 1.1 & 0.48 & Middle \\
\hline $\begin{array}{l}\text { House \& } \\
\text { Garden }\end{array}$ & 3.60 & 12 & April 2008 & $\begin{array}{l}\text { Food and } \\
\text { homes }\end{array}$ & 792 & 1.6 & 2.0 & 1.1 & 0.55 & Least \\
\hline $\begin{array}{l}\text { House } \\
\text { Beautiful }\end{array}$ & 3.10 & 11 & May 2008 & $\begin{array}{l}\text { Food and } \\
\text { homes }\end{array}$ & 505 & 1.0 & 1.4 & 0.6 & 0.43 & Most \\
\hline Ideal Home & 3.10 & 12 & May 2008 & $\begin{array}{l}\text { Food and } \\
\text { homes }\end{array}$ & 1050 & 2.2 & 2.6 & 1.6 & 0.62 & Least \\
\hline Marie Claire & 3.20 & 12 & May 2008 & $\begin{array}{l}\text { Lifestyle and } \\
\text { beauty }\end{array}$ & 1217 & 2.5 & 3.3 & 1.6 & 0.48 & Middle \\
\hline $\begin{array}{l}\text { Mother \& } \\
\text { Baby }\end{array}$ & 2.60 & 12 & May 2008 & $\begin{array}{l}\text { General } \\
\text { interest }\end{array}$ & 678 & 1.4 & 1.2 & 1.6 & 1.33 & Least \\
\hline Prima & 2.50 & 12 & May 2008 & $\begin{array}{l}\text { General } \\
\text { interest }\end{array}$ & 684 & 1.4 & 1.6 & 1.2 & 0.75 & Least \\
\hline Red & 3.30 & 12 & April 2008 & $\begin{array}{l}\text { Lifestyle and } \\
\text { beauty }\end{array}$ & 693 & 1.4 & 2.1 & 0.6 & 0.29 & Most \\
\hline Vogue & 3.80 & 12 & April 2008 & $\begin{array}{l}\text { Lifestyle and } \\
\text { beauty }\end{array}$ & 1230 & 2.5 & 3.3 & 1.5 & 0.45 & Most \\
\hline $\begin{array}{l}\text { Woman \& } \\
\text { Home }\end{array}$ & 3.40 & 12 & May 2008 & $\begin{array}{l}\text { General } \\
\text { interest }\end{array}$ & 813 & 1.7 & 2.2 & 1.1 & 0.50 & Middle \\
\hline
\end{tabular}

${ }^{1}$ Data obtained from National Readership Survey (NRS), October 2006 - September 2007, restricted to adults aged 15 years or older, see reference[16]. ${ }^{2}$ As calculated by NRS. ${ }^{3}$ All adults aged 15 years and older. ${ }^{4}$ Adults aged 15 years and older in non-manual social classes, as defined and calculated by NRS. ${ }^{5}$ Adults aged 15 years and older in manual social classes, as defined and calculated by NRS. ${ }^{6}$ Ratio of percentage of population in manual social classes (C2DE) who read the magazine:percentage of population in non-manual social classes $(A B C 1)$ who read the magazine. ${ }^{7}$ Tertiles of $C 2 D E: A B C 1$ ratio; most $=$ most affluent readership, lowest $C 2 D E: A B C 1$ ratio; least = least affluent readership, highest $C 2 D E: A B C 1$ ratio; middle = intermediate readership, intermediate $C 2 D E: A B C 1$ ratio.

(3.9\%) were food advertisements. Table 2 shows the number of publications, cover price, issues, pages, advertisements and food advertisements broken down by season, magazine type and affluence tertile. There was evidence that the percentage of pages that were advertisements, the percentage of advertisements that were for food, the percentage of pages that were food advertisements, and the percentage of advertising pages that were for food all varied across season, magazine type and affluence tertile ( $\mathrm{p}<0.001$ in all cases). Food advertisements were most prevalent in summer, general interest magazines, and magazines in the most affluent tertile and least prevalent in spring and magazines in the least affluent tertile. There was a statistically significant correlation between cover price and C2DE:ABC1 ratio $(r=$ $-0.50, p<0.05)$ indicating that magazines with greater proportions of more affluent readers tended to be more expensive.

Table 3 shows the distribution of food advertisements across the seven food groups, both overall and by season, magazine type and affluence tertile. In 261 (18.9\%) food advertisements, more than one branded food product was shown. However, in all these cases all branded foods were in the same food group. The most common 
Table 2 Advertisements in UK monthly women's magazines overall and by season, magazine type and relative affluence of readers

\begin{tabular}{|c|c|c|c|c|c|c|c|c|}
\hline & $\begin{array}{l}\mathrm{N} \\
\text { publications }\end{array}$ & $\begin{array}{l}\mathrm{N} \\
\text { issues }\end{array}$ & $\begin{array}{l}\mathrm{N} \\
\text { pages }\end{array}$ & $\begin{array}{l}\mathrm{N} \\
\text { adverts }\end{array}$ & $\begin{array}{l}\mathrm{N}(\%) \text { pages that } \\
\text { were adverts }\end{array}$ & $\begin{array}{l}N(\%) \text { adverts that } \\
\text { were for food }\end{array}$ & $\begin{array}{l}N(\%) \text { pages that } \\
\text { were food adverts }\end{array}$ & $\begin{array}{l}\% \text { advertising pages } \\
\text { that were for food }\end{array}$ \\
\hline All & 18 & 213 & $\begin{array}{l}49 \\
289\end{array}$ & 35053 & 19543 (39.6) & $1380(3.9)$ & $1452(2.9)$ & 7.4 \\
\hline \multicolumn{9}{|l|}{ Season } \\
\hline Spring & 18 & 52 & $\begin{array}{l}12 \\
145\end{array}$ & 8626 & 4812 (39.6) & $236(2.7)$ & $241(2.0)$ & 5.0 \\
\hline Summer & 18 & 54 & $\begin{array}{l}11 \\
519\end{array}$ & 8454 & 4445 (38.6) & $400(4.7)$ & $423(3.7)$ & 9.5 \\
\hline Autumn & 18 & 54 & $\begin{array}{l}14 \\
269\end{array}$ & 10039 & $6079(42.6)$ & $428(4.3)$ & $450(3.2)$ & 7.4 \\
\hline Winter & 18 & 53 & $\begin{array}{l}11 \\
356\end{array}$ & 7934 & 4207 (37.0) & $316(4.0)$ & $339(3.0)$ & 8.1 \\
\hline $\begin{array}{l}\chi^{2}(p- \\
\text { value }) ; d f= \\
3\end{array}$ & & & & & $89.6(<0.001)$ & $49.9(<0.001)$ & $62.7(<0.001)$ & $71.5(<0.001)$ \\
\hline \multicolumn{9}{|l|}{$\begin{array}{l}\text { Magazine } \\
\text { type }\end{array}$} \\
\hline $\begin{array}{l}\text { Lifestyle \& } \\
\text { beauty }\end{array}$ & 8 & 94 & $\begin{array}{l}25 \\
473\end{array}$ & 16088 & 11039 (43.3) & $562(3.5)$ & $593(2.3)$ & 5.4 \\
\hline $\begin{array}{l}\text { Food \& } \\
\text { homes }\end{array}$ & 6 & 71 & $\begin{array}{l}14 \\
160\end{array}$ & 13577 & $5202(36.7)$ & $362(2.7)$ & $370(2.6)$ & 7.1 \\
\hline $\begin{array}{l}\text { General } \\
\text { interest }\end{array}$ & 4 & 48 & 9656 & 5388 & $3303(34.2)$ & $456(8.5)$ & $490(5.1)$ & 14.8 \\
\hline $\begin{array}{l}\chi^{2}(p- \\
\text { value }) ; d f= \\
2\end{array}$ & & & & & $314.4(<0.001)$ & $358.2(<0.001)$ & $192.4(<0.001)$ & $331.9(<0.001)$ \\
\hline \multicolumn{9}{|l|}{$\begin{array}{l}\text { Affluence } \\
\text { tertile }\end{array}$} \\
\hline Least & 6 & 71 & $\begin{array}{l}12 \\
882\end{array}$ & 9231 & $4256(33.0)$ & $255(2.8)$ & $259(2.0)$ & 6.1 \\
\hline Middle & 6 & 72 & $\begin{array}{l}20 \\
057\end{array}$ & 12227 & 8410 (41.9) & $496(4.1)$ & $517(2.6)$ & 6.1 \\
\hline Most & 6 & 70 & $\begin{array}{l}16 \\
350\end{array}$ & 13595 & $6876(42.1)$ & $629(4.6)$ & $676(4.1)$ & 9.8 \\
\hline $\begin{array}{l}\chi^{2}(p- \\
\text { value }) ; d f= \\
2\end{array}$ & & & & & $318.5(<0.001)$ & $51.2(<0.001)$ & $129.7(<0.001)$ & $88.9(<0.001)$ \\
\hline
\end{tabular}

Adverts = advertisements; $\mathrm{df}=$ degrees of freedom

food group represented was 'food and drinks high in fat and/or sugar' ( $28.0 \%$ of food advertisements); the least common category was 'fruits \& vegetables' (2.0\%). There were significant seasonal variations in the proportion of food advertisements in the 'alcohol' and 'bread, rice, potatoes, pasta' groups. Advertisements for 'bread, rice, potatoes, pasta' were all most frequent in spring and least common in summer. Advertisements for 'alcohol' were most common in winter and least common in spring.

There were also significant variations in the proportion of food advertisements in the 'alcohol' and 'bread, rice, potatoes, pasta' food groups across magazine types. Advertisements for 'alcohol' were most common in lifestyle and beauty magazines and least common in general interest magazines. Advertisements for 'bread, rice, potatoes, pasta' were most common in food \& homes magazines and least common in lifestyle and beauty magazines.

There were statistically significant variations across socio-economic tertiles in the proportion of food advertisements in the 'alcohol' and 'meat, fish, eggs, beans' categories. 'Alcohol' was most common in the middle tertile of magazines and least common in the least affluent tertile. Advertisements for 'meat, fish, eggs, beans' were most common in the most affluent tertile of magazines and least common in the middle tertile.

\section{Discussion}

\section{Summary of findings}

This is the first comprehensive study of the extent and nature of food advertisements in UK monthly women's 
Table 3 Categories of branded foods advertised in UK monthly women's magazines overall and by season, magazine type and relative affluence of readers

\begin{tabular}{|c|c|c|c|c|c|c|c|}
\hline & Alcohol & $\begin{array}{l}\text { Bread, rice } \\
\text { potatoes, } \\
\text { pasta }\end{array}$ & $\begin{array}{l}\text { Food \& drinks } \\
\text { high } \\
\text { in fat and/or } \\
\text { sugar }\end{array}$ & $\begin{array}{l}\text { Fruits } \& \\
\text { vegetables }\end{array}$ & $\begin{array}{l}\text { Meat, fish, eggs, } \\
\text { beans }\end{array}$ & $\begin{array}{l}\text { Milk \& } \\
\text { dairy } \\
\text { foods }\end{array}$ & $\begin{array}{l}\text { Other } \\
\text { foods }\end{array}$ \\
\hline All, n(\%) & $139(10.1)$ & $264(19.3)$ & $386(28.0)$ & $28(2.0)$ & $57(4.1)$ & $218(15.8)$ & $288(20.9)$ \\
\hline \multicolumn{8}{|l|}{ Season } \\
\hline Spring, $n(\%)$ & $9(3.8)$ & $64(27.1)$ & $53(22.5)$ & $6(2.5)$ & $18(7.6)$ & $36(15.3)$ & $50(21.2)$ \\
\hline Summer, n(\%) & $45(11.3)$ & $60(15.0)$ & $135(33.8)$ & $5(1.5)$ & $10(2.5)$ & $67(16.8)$ & $77(19.3)$ \\
\hline Autumn, n(\%) & $40(9.4)$ & $90(21.0)$ & $118(27.6)$ & $8(1.9)$ & $16(3.7)$ & $70(16.4)$ & $86(20.1)$ \\
\hline Winter, n(\%) & $45(14.2)$ & $50(15.8)$ & $80(25.3)$ & $8(2.5)$ & $13(4.1)$ & $45(14.2)$ & $75(23.7)$ \\
\hline$\chi^{2}$ (p-value), $d f=3$ & $17.1(0.001)$ & $17.4(0.001)$ & $11.3(0.010)$ & $1.3(0.721)$ & $10.1(0.017)$ & $1.0(0.801)$ & $2.4(0.498)$ \\
\hline \multicolumn{8}{|l|}{ Magazine type } \\
\hline $\begin{array}{l}\text { Lifestyle \& beauty, n } \\
\text { (\%) }\end{array}$ & $114(20.3)$ & 69 (12.3) & $165(29.4)$ & $5(0.9)$ & $15(2.7)$ & $91(6.2)$ & $103(18.3)$ \\
\hline Food \& homes, n(\%) & $21(5.8)$ & $95(26.2)$ & $97(26.8)$ & $9(2.5)$ & $16(4.4)$ & $45(12.4)$ & $79(21.8)$ \\
\hline $\begin{array}{l}\text { General interest, } \mathrm{n} \\
(\%)\end{array}$ & $4(0.9)$ & $100(21.9)$ & $124(27.2)$ & $14(3.1)$ & $26(5.7)$ & $82(18.0)$ & $106(23.3)$ \\
\hline$\chi^{2}$ (p-value), df $=2$ & $\begin{array}{l}114.6 \\
(<0.001)\end{array}$ & $31.2(<0.001)$ & $0.9(0.630)$ & $6.5(0.038)$ & $6.0(0.051)$ & $4.8(0.091)$ & $4.0(0.138)$ \\
\hline \multicolumn{8}{|l|}{ Affluence tertile } \\
\hline Least, n(\%) & $7(2.8)$ & $57(22.4)$ & $81(31.8)$ & $5(2.0)$ & $8(3.1)$ & $36(14.1)$ & $61(23.9)$ \\
\hline Middle, n(\%) & $87(17.5)$ & $77(15.5)$ & $145(29.2)$ & $5(1.0)$ & $11(2.2)$ & $74(14.9)$ & 97 (19.6) \\
\hline Most, n(\%) & $45(7.2)$ & $130(20.7)$ & $160(25.4)$ & $18(2.9)$ & $38(6.0)$ & $108(17.2)$ & $130(20.7)$ \\
\hline$\chi^{2}$ (p-value),$d f=2$ & $\begin{array}{l}51.6 \\
(<0.001)\end{array}$ & $6.8(0.033)$ & $4.2(0.121)$ & $4.8(0.091)$ & $11.0(0.004)$ & $1.7(0.423)$ & $2.0(0.373)$ \\
\hline
\end{tabular}

$\mathrm{df}=$ degrees of freedom

magazines, covering a wide range of popular magazines published across a full year. Although advertising made up $40 \%$ of the pages of the magazines studied, food advertisements only accounted for $3 \%$ of magazine pages. As previously [6,7,10-12,14,15], 'less healthy' foods were prominent amongst food advertisements with 'food and drinks high in fat and/or sugar' accounting for more than a quarter of food advertisements. There were a number of variations in the prevalence of food advertisements according to season, magazine type and socio-economic profile of readers. Differences in the food categories that advertised foods fell into were less common. Advertisements for alcohol were not particularly common and accounted for only $10.1 \%$ of food advertisements.

\section{Strengths and weaknesses of methods}

We included a much wider range of publications and issues than previously $[6,7,11,15]$. This allowed us to explore magazine food advertising across a wide variety of publications and to study differences in food advertising according to season and magazine type.

Our primary unit of analysis was the individual advertisement. This assumes that all advertisements have the same impact. However, food advertisements vary substantially and there are likely to be differences in the power of different advertisements to influence dietary choices - although it is difficult to see how this could be taken into account in this sort of study.

We only included branded products in our analysis and did not collect any information on non-branded food products shown in advertisements or elsewhere in magazines. Thus any incidental products shown in food advertisements (e.g. milk in an advertisements for a branded breakfast cereal) were excluded. These incidental products may have important influences on consumers', but to date this area has received little research attention. One study on television advertisements found that when non-branded food products were shown in advertisements they tended to be 'more healthy' than the branded products being promoted - suggesting that 'less healthy' branded products may be being promoted to a 'more healthy' food context in order to give them the 'air of healthiness' [19]. Future work could explore differences and similarities in branded and non-branded foods shown both in advertisements and elsewhere in magazines.

We used the food groups in the UK Food Standard's Agency's 'Eatwell plate' [18], plus two extra groups, to categorise advertised foods. Whilst this approach grounds our analysis in current UK public health context, many of the seven food groups used are quite 
diverse (see Additional file 1, Table S1). For example, the two most prevalent sub-categories in the 'food and drinks high in fat and/or sugar' food group are oils, fats and spreads and chocolate - two rather different types of food, eaten in different quantities on different occasions.

Furthermore, where individual foods fall within the 'Eatwell plate' categories, and our extension of them, may not always be obvious on first glance. We used the detailed 'Eatwell plate' guidance to help us with categorisation and introduced the category 'other foods' for those foods that we found difficult to place in one of the existing 'Eatwell plate' groups. Whilst there may be some apparent overlap between 'Eatwell plate' categories (e.g. cheese is categorised as 'milk \& diary' but could also be considered 'high in fat and/or sugar'), in practice the detailed guidance provided on the categories clarifies where individual foods should be placed.

Although we could have used a categorisation scheme with more groups, this would arguably have made our results harder to interpret. No food group categorisation is perfect and there is always a balance to be struck between detail and interpretability.

\section{Interpretation of results}

The monthly magazines studied devoted a similar proportion of their pages to food advertising as was found in a previous study of weekly magazines (3\% here versus $4 \%$ in weekly magazines) [14]. However, whilst $16 \%$ of advertising pages were devoted to food in the weekly magazines, only $7 \%$ of advertising pages were found to be food in the monthly magazines studied here. Data from UK television indicates that around 15\% of advertisements are for food [20]. Thus, food advertisements make up a relatively small component of the monthly magazines studied, and appear to make a smaller contribution to overall advertisement in monthly magazines than in other media. This highlights how different advertising in different media is and that results are not necessarily generalisable across media.

As with previous studies of print advertising $[6,7,10-12,14,15]$, we found that food advertising in popular UK monthly women's magazines were dominated by foods in the 'food \& drinks high in fat and/or sugar' group. The Eatwell plate suggest that 'balanced diet' contains "plenty" of 'fruit and vegetables', and 'bread, rice, potatoes, pasta'; "some" 'milk and dairy' foods and 'meat, fish, eggs, beans'; and "just a little" 'food and drinks high in fat and/or sugar'. Whilst it is difficult to compare our results directly to these rather non-specific suggestions, it is clear that food advertisements appear to over-represent 'food and drinks high in fat and/or sugar' and under-represent foods in all other groups, when compared to this definition of a 'balanced diet'.
One possible reason for the high volume of advertisements for 'food and drinks high in fat and/or sugar' and the low volume of advertisements for 'fruit and vegetables' is differences in what sorts of foods tend to be processed, and branded. For example, fruit and vegetables are rarely products that are branded, and when they are, this generally occurs when they have been processed in some way - e.g. dried, juiced, frozen. In contrast, 'food and drinks high in fat and/or sugar' tend to be highly processed foods where the opportunity for innovation and diversity, and hence branding, is ripe.

Some of the variations in food advertising seen across season may reflect social and cultural events associated with those seasons. For example, advertisements for alcohol were most prevalent in winter, presumably reflecting the impact of Christmas and New Year festivities when alcohol consumption tends to peak [21]. It is difficult to speculate whether there is a causal relationship operating here and, if so, in what direction. For example, it is possible both that increases in alcohol advertising around Christmas and New Year lead to increased consumption, or that advertisers merely reflect increased consumption at these times of year in their marketing. The reality is likely to be a mixture of both, with food and alcohol companies attempting both to increase their market share during times of peak consumption, and contributing to increased consumption through their marketing.

Similarly, differences in food advertising across magazine types may reflect the different readerships of different magazines. The only statistically significant differences in food advertisements between magazine types were in relation to the proportion of advertisements in the 'alcohol' and 'bread, rice, potatoes, pasta' categories. Alcohol accounted for more than $20 \%$ of food advertisements in 'lifestyle and beauty' magazines but was almost absent from other magazines. This may reflect the younger age of readers of 'lifestyle and beauty' magazines [16]. Again, it is likely both that marketers reflect the lifestyles of the readers in the magazines they target and that advertisements contribute to lifestyle differences between different demographic groups.

Differences in food advertising according to the socioeconomic balance of readers of different magazines were not as marked as has been previously reported [14]. In particular, the clear trends for less healthy foods to be advertised more to less affluent readers and alcohol to be advertised more to more affluent readers, found in UK weekly magazines, were not seen here. Although, there was a non-significant trend for advertisements for 'food and drinks high in fat and/or sugar' to be more prevalent in magazines with less affluent readerships. This may be because of the much more affluent 
readership of monthly, compared to weekly, magazines. The C2DE:ABC1 ratio was $<1$ in all but one of the monthly magazines studied here and $\leq 0.5$ in $50 \%$ of them. In contrast, it was $\geq 1$ in $80 \%$ of weekly magazines studied [14]. It is possible that differences in food advertising according to the socio-economic profile of readers are not seen at the extremes of the socio-economic distribution that monthly magazines appear to represent. The clear association between our marker of the socioeconomic balance of readers (C2DE: $\mathrm{ABC} 1$ ratio) and cover price indicates that this is likely to be an accurate marker of socio-economic position.

\section{Implications for policy and research}

Although substantial work has now documented the extent of food advertising in different spheres [e.g. $[4,5,14,22-24]]$, less work has focused on how food advertising is perceived and understood by both child and adult consumers. Further work is required to understand, for example, how different people respond to food advertisements both in print and elsewhere, and whether particular marketing techniques are particularly harmful in terms of effects on dietary preferences and consumption.

The advertising landscape and media is continually evolving. For example, there has been a decline in readership of many magazines over recent years. Comparison of the most recent readership figures from 2010 with those in 2007 (used to guide the research described here) indicate an average decline of around 10\% across publications included in this research [16]. It is also possible that the recent introduction of regulations on television food advertising to children in the UK [25] has led to knockon changes in food advertising in other media. Other recent developments include the rise of on-line and other non-traditional advertising, and new UK regulations allowing product placement on television made in the UK [26]. Policy makers and researchers need to be aware of the need to keep reappraising their strategies and knowledge in the light of industry developments.

Substantial research has confirmed that food advertising across a variety of different mediums tends to focus on 'less healthy' food $[4,5,27]$. The current work contributes to this evidence by highlighting the complexity of food advertising in relation to target audience and time of year. There is growing consensus that food promotion directed at children has a negative impact on food preferences and choice [4,5], and this has led to regulation of television food advertising to children in a number of contexts [28]. There is now also emerging evidence that adults are also influenced by food advertisements [29]. Although food advertisements were relatively rare in the magazines studied, by regulating food advertising in some, but not all, media, the UK government is sending mixed messages about its desire to tackle food marketing. A more consistent approach across all media may be warranted and it may now be time to consider regulation of all food advertising - not just that targeted at children, and not just that on television.

\section{Conclusions}

Food and drink advertisements represented only a small proportion of advertisements in UK women's monthly magazines. Food and drink advertisements in these magazines feature a high proportion of 'less healthy' foods. There were a number of differences across season, magazine type and according to the socio-economic profile of readers in the prevalence of food and drink advertisements. Fewer differences were seen in the type of food and drinks advertised.

\section{Additional material}

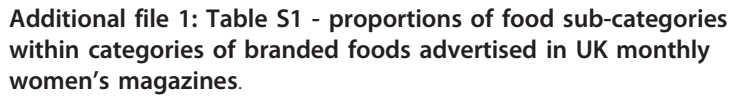

\section{Acknowledgements}

JA and MW receive salary support from Fuse - the Centre for Translational Research in Public Health which is funded by the British Heart Foundation, Cancer Research UK, Economic and Social Research Council, Medical Research Council, and the National Institute for Health Research, under the auspices of the UK Clinical Research Collaboration.

\section{Authors' contributions}

JA \& MW conceived the idea for this work. ES collected the data. JA \& ES analysed the data. JA \& ES drafted the manuscript. All authors reviewed and provided critical comments on previous versions of the manuscript. All authors read and approved the final manuscript.

\section{Competing interests}

The authors declare that they have no competing interests.

Received: 9 December 2010 Accepted: 23 May 2011

Published: 23 May 2011

\section{References}

1. Beaglehole R, Irwin A, Prentice T: World Health Report 2003 Geneva: World Health Organization; 2003.

2. Department of Health: Choosing a better diet: a food and health action plan London: Department of Health; 2005.

3. Butland B, Jebb S, Kopelman P, McPherson K, Thomas S, Mardell J, Parry V: Foresight Tackling Obesities: future choices - project report London: Government Office for Science; 2007.

4. Cairns G, Angus K, Hastings G: The extent, nature and effects of food promotion to children: a review of the evidence to December 2008. Prepared for the World Health Organization Geneva: Institute for Social Marketing, University of Stirling \& The Open University, United Kingdom; 2009.

5. McGinnis J, Goolman J, Kraak V: Food marketing to children and youth: threat or opportunity? Washington, DC: The National Academies Press; 2006.

6. Hickman B, Gates G, Dowdy R: Nutrition Claims in Advertising: A Study of Four Women's Magazines. Journal of Nutrition Education 1993, 25:227-235.

7. Hill JM, Radimer KL: Health and nutrition messages in food advertisements: A comparative content analysis of young and mature Australian women's magazines. Journal of Nutrition Education 1996, 28:313-320. 
8. McPheters R: The Effectiveness of Print Advertising. Journal of Advertising Research 1991, 31.

9. HFSS advertising restrictions - experience to date and next steps. [http:// stakeholders.ofcom.org.uk/binaries/research/tv-research/briefing.pdf], Accessed: 2 March 2011.

10. Campo S, Mastin T: Placing the Burden on the Individual: Overweight and Obesity in African American and Mainstream Women's Magazines. Health Communication 2007, 22:229-240.

11. Pratt C, Pratt C: Comparative Content Analysis of Food and Nutrition Advertisements in Ebony, Essence and Ladies' Home Journal. Journal of Nutrition Education 1995, 27:11-17.

12. Pratt C, Pratt C: Nutrition Advertisements in Consumer Magazines. Journal of Black Studies 1996, 26:504-523.

13. Department of Health and Human Services: Healthy People 2010. 2 edition. Washington DC: Government Printing Office; 2000.

14. Adams J, White M: Socio-economic and gender differences in nutritional content of foods advertised in popular UK weekly magazines. European Journal of Public Health 2009, 19:144-149.

15. Barr SI: Nutrition in Food Advertising: Content Analysis of a Canadian Women's Magazine, 1928-1986. Journal of Nutritional Education 1989, 21:64-72.

16. Top Line Readership. [http://www.nrs.co.uk/toplinereadership.html], Accessed: 3 March 2011.

17. The Office of Communication: The Ofcom Broadcast Code London: The Stationery Office; 2005.

18. The Eatwell Plate. [http://www.nhs.uk/Livewell/Goodfood/Documents/ Eatwellplate.pdf], Accessed: 28 March 2011.

19. Adams J, Tyrrell R, White M: Do television food advertisements portray advertised foods in a 'healthy' food context? Br J Nutr 2011, 105:810-815.

20. Tyrrell R, Adams J, Adamson A, White M: The new TV diet - evaluating the effect of the UK 2007 OfCom restrictions on television food advertising to children. UK Society for Behavioural Medicine 5th Scientific Meeting Southampton, UK; 2009.

21. Cho Y, Johnson T, Fendrich M: Monthly variations in self-reports of alcohol consumption. J Stud Alcohol 2001, 62:268-272.

22. Adams J, Hennessy-Priest J, Ingimarsdóttir S, Sheeshka J, Østbye T, White M: Changes in food advertisements during 'prime-time' television from 1991 to 2006: a UK-Canada comparison. Br J Nutr 2009, 102:584-593.

23. Adams J, Hennessy-Priest K, Ingimarsdóttir S, Sheeshka J, Østbye T, White M: Food advertising during children's television in Canada and the UK. Arch Dis Child 2009, 94:658-662.

24. Adams J, Ganiti E, White M: Socio-economic differences in outdoor food advertising in a city in Northern England. Public Health Nutrition .

25. OfCom: Television advertising of food and drink products to children - final statement London: Ofcom; 2007.

26. Product placement on TV. [http://consumers.ofcom.org.uk/2011/02/ product-placement-on-tv/, Accessed: 20113 March.

27. Gallo A: Food Advertising in the United States. In America's Eating Habits. Changes and Consequences. Volume Agriculture Information Bulletin No. 750. Edited by: Fogel R. U.S. Department of Agriculture, Economic Research Service, Food and Rural Economics Division; 1999:

28. Caraher M, Landon J, Dalmeny K: Television advertising and children: lessons from policy development. Public Health Nutrition 2006, 9:596-605.

29. Harris J, Bargh J, Brownell K: Priming effects of television food advertising on eating behavior. Health Psychol 2009, 28:404-413.

\section{Pre-publication history}

The pre-publication history for this paper can be accessed here: http://www.biomedcentral.com/1471-2458/11/368/prepub

\section{doi:10.1186/1471-2458-11-368}

Cite this article as: Adams et al:: Variations in food and drink advertising in UK monthly women's magazines according to season, magazine type and socio-economic profile of readers: a descriptive study of publications over 12 months. BMC Public Health 2011 11:368. 